Water-Quality Data for Pharmaceuticals and Other Organic Wastewater Contaminants in Ground Water and in Untreated Drinking Water Sources in the United States, 2000-01

Open-File Report 2008-1293 



\section{Water-Quality Data for Pharmaceuticals and Other Organic Wastewater Contaminants in Ground Water and in Untreated Drinking Water Sources in the United States, 2000-01}

By Kimberlee K. Barnes, Dana W. Kolpin, Michael J. Focazio, Edward T. Furlong, Michael T. Meyer, Steven D. Zaugg, Sheridan K. Haack, Larry B. Barber, and E. Michael Thurman

Open-File Report 2008-1293 


\section{U.S. Department of the Interior DIRK KEMPTHORNE, Secretary}

\section{U.S. Geological Survey \\ Mark D. Myers, Director}

\section{U.S. Geological Survey, Reston, Virginia: 2008}

For product and ordering information:

World Wide Web: http://www.usgs.gov/pubprod

Telephone: 1-888-ASK-USGS

For more information on the USGS--the Federal source for science about the Earth, its natural and living resources, natural hazards, and the environment:

World Wide Web: http://www.usgs.gov

Telephone: 1-888-ASK-USGS

Any use of trade, product, or firm names is for descriptive purposes only and does not imply endorsement by the U.S. Government.

Although this report is in the public domain, permission must be secured from the individual copyright owners to reproduce any copyrighted materials contained within this report.

Suggested citation:

Barnes, K.K., Kolpin, D.W., Focazio, M.J., Furlong, E.T., Meyer, M.T., Zaugg, S.D., Haack, S.K., Barber, L.B., and Thurman, E.M., 2008, Water-quality data for pharmaceuticals and other organic wastewater contaminants in ground water and in untreated drinking water sources in the United States, 2000-01: U.S. Geological Survey Open-File Report 2008-1293, 7 p. plus tables. 


\section{Contents}

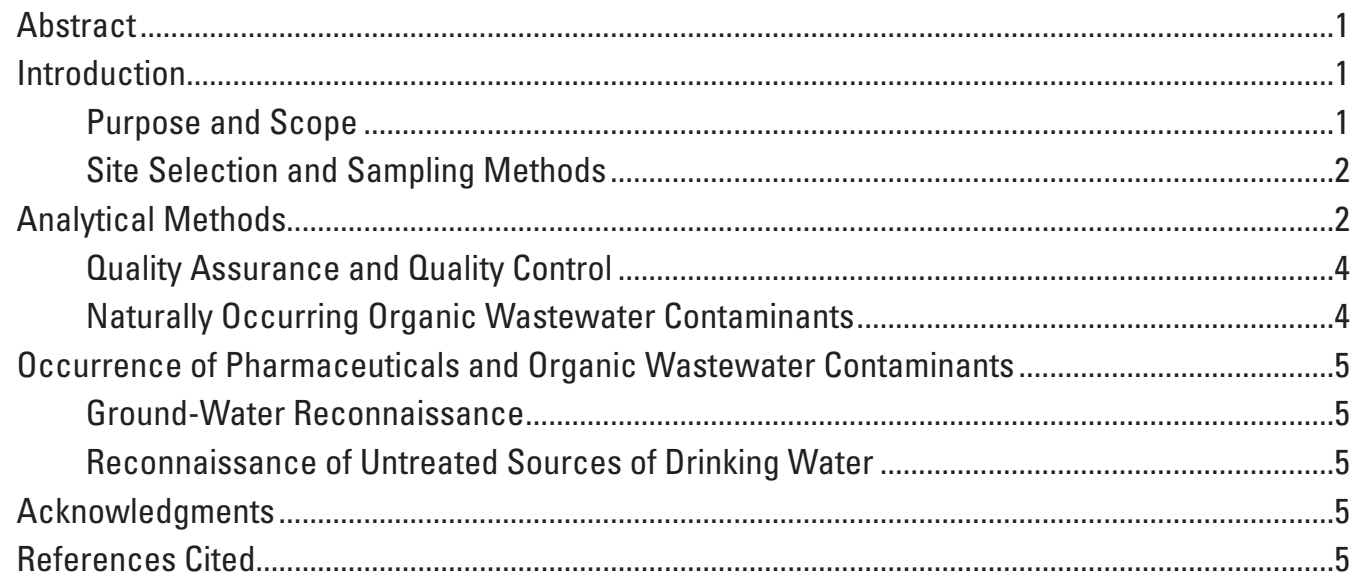

\section{Figures}

1. Map showing location of surface- and ground-water sampling sites, 2000 through 2001

\section{Tables}

[Click on table title to view in Excel format]

1. Surface- and ground-water sites analyzed in 2000 and 2001

2. Samples collected from surface- and ground-water sites analyzed for selected antibiotic analytes in 2000 and 2001

3. Samples collected from surface- and ground-water sites analyzed for selected human pharmaceutical analytes in 2000 and 2001

4. Samples collected from surface- and ground-water sites analyzed for selected organic wastewater analytes in 2000 and 2001

5. Quality-assurance samples from surface- and ground-water sites analyzed in 2000 and 2001

6. Naturally occurring compounds 


\section{Conversion Factors}

\begin{tabular}{|c|c|c|}
\hline Multiply & By & To obtain \\
\hline \multicolumn{3}{|c|}{ Volume } \\
\hline liter (L) & 33.82 & ounce, fluid (fl. oz) \\
\hline liter $(\mathrm{L})$ & 2.113 & pint $(p t)$ \\
\hline liter (L) & 1.057 & quart (qt) \\
\hline liter (L) & 0.2642 & gallon (gal) \\
\hline liter (L) & 61.02 & cubic inch $\left(\mathrm{in}^{3}\right)$ \\
\hline
\end{tabular}

Concentrations of chemical constituents in water are given either in milligrams per liter ( $\mathrm{mg} / \mathrm{L}$ ) or micrograms per liter $(\mu \mathrm{g} / \mathrm{L})$.

NOTE TO USGS USERS: Use of liter (L) as a special name for cubic decimeter $\left(\mathrm{dm}^{3}\right)$ is restricted to the measurement of liquids and gases. No prefix other than milli should be used with liter. 


\title{
Water-Quality Data for Pharmaceuticals and Other Organic Wastewater Contaminants in Ground Water and in Untreated Drinking Water Sources in the United States, 2000-01
}

\author{
By Kimberlee K. Barnes, Dana W. Kolpin, Michael J. Focazio, Edward T. Furlong, Michael T. Meyer, \\ Steven D. Zaugg, Sheridan K. Haack, Larry B. Barber, and E. Michael Thurman
}

\section{Abstract}

This report presents water-quality data from two nationwide studies on the occurrence and distribution of organic wastewater contaminants. These data are part of the continuing effort of the U.S. Geological Survey Toxic Substances Hydrology Program to collect baseline information on the environmental occurrence of pharmaceuticals and other organic wastewater contaminants.

In 2000, samples were collected from 47 ambient ground-water sites (not drinking-water wells) in 18 states and analyzed for 65 organic wastewater contaminants. In the summer of 2001, samples were collected from 74 sources of raw, untreated, drinking water in 25 states and Puerto Rico and analyzed for 100 organic wastewater contaminants. These sources comprise 25 ground-water and 49 surface-water sources of drinking water serving populations ranging from one family to more than 8 million people. Site selection for both studies focused on areas known or suspected to contain sources of animal and/or human wastewater.

The five most frequently detected compounds in samples collected from ambient ground-water sites are N,N-diethyltoluamide (35 percent, insect repellant), bisphenol A (30 percent, plastic- and epoxy-manufacturing ingredient), tri(2chloroethy) phosphate (30 percent, fire retardant), sulfamethoxazole (23 percent, veterinary and human antibiotic), and 4-octylphenol monoethoxylate (19 percent, detergent metabolite). The five most frequently detected organic wastewater contaminants in samples of untreated drinking water from surface-water sources are cholesterol (59 percent, natural sterol), metolachlor (53 percent, herbicide), cotinine (51 percent, nicotine metabolite), $\beta$-sitosterol (37 percent, natural plant sterol), and 1,7-dimethylxanthine (27 percent, caffeine metabolite). The five most frequently detected organic wastewater contaminants in samples of untreated drinking water from ground-water sources are tetrachloroethylene (24 percent, solvent), carbamazepine (20 percent, pharmaceutical), bisphenol
A (20 percent, plastic- and epoxy-manufacturing ingredient), 1,7-dimethylxanthine (16 percent, caffeine metabolite), and tri(2-chloroethyl) phosphate (12 percent, fire retardant).

\section{Introduction}

Tens of thousands of manufactured and natural organic compounds, such as pharmaceuticals, plastic- and epoxy-manufacturing ingredients, surfactants, flame retardants, steroids, and other trace organic compounds currently (2008) in use have the potential to enter water resources through a variety of pathways (Heberer, 2002a). Many of these compounds are now widely recognized as environmental contaminants (Hignite and Azarnoff, 1977; Daughton and Ternes, 1999; Halling-Sorensen and others, 2002) and their occurrence has been documented in ground- and surface-water resources around the world including those used for public-drinking water (Ternes, 1998; Stumpf and others, 1999; Heberer and others, 2001; Kolpin and others, 2002; Heberer, 2002b; Metcalf and others, 2003; Ashton and others, 2004; Hohenblum and others, 2004; Wiegel and others, 2004; Moldovan, 2006; Kim and others, 2007). Although wastewater treatment plant effluents are only one potential source, human and animal wastewater effluents are among the most important associated source pathways for most of these compounds into the aquatic environment (Ternes, 1998; Paxeus, 2004; Clara and others, 2005; Glassmeyer and others, 2005; Lindqvist and others, 2005; Miao and others, 2005; Reiner and others, 2007). For simplicity, the collective term "organic wastewater contaminants" (OWCs) is used for trace organic compounds targeted in this study or any study cited here.

\section{Purpose and Scope}

The purpose of this report is to present the results of datacollection activities for two national-scale studies. The first, 
a national ground-water reconnaissance, sampled 47 ambient ground-water sites (not drinking-water wells) in 18 states in 2000 (fig. 1 and table 1). The samples collected were analyzed for 65 OWCs. The second study collected samples from 25 ground- and 49 surface-water sites representing raw, untreated drinking water sources in the summer of 2001 in 25 states and Puerto Rico (fig. 1 and table 1). Both studies were part of the continued effort of the U.S. Geological Survey (USGS) Toxics Substances Hydrology Program (http://toxics.usgs.gov/ regional/emc/) to collect data on a national scale in the United States. The interpretive summaries and more details of these studies are published in Barnes and others (2008) and Focazio and others (2008).

- Table 1. Surface- and ground-water sites analyzed in 2000 and 2001 (Excel format).

\section{Site Selection and Sampling Methods}

Information on the occurrence of OWCs in ambient ground water and raw, untreated ground and surface water used as sources of drinking water is sparse; therefore, both studies sampled sites in areas thought to be susceptible to contamination from either animal or human wastewaters. A network of 47 ambient ground-water sites consisting of 42 wells, 3 springs, and 2 sumps (fig. 1 and table 1) was sampled in 2000; the sites are located down gradient from landfills, unsewered residential developments, or animal feedlots. These sites were not necessarily used as sources of drinking water, but provide a variety of geohydrologic environments with potential sources of OWCs.

Samples of raw, untreated ground and surface water were collected in the summer of 2001 from areas known or suspected to have at least some wastewater effluent sources in upstream or upgradient areas serving a range of populations (fig. 1 and table 1).

All water samples were collected by USGS personnel using consistent, standard, field protocols and procedures designed to obtain a sample representative of the untreated (or raw) ground- or surface-water source (U.S. Geological Survey, 2006). A composite water sample was collected at each site and split into appropriate containers for shipment. For those bottles requiring filtration, water was passed through a 0.7 micrometer pore-size, baked, glass-fiber filter in the field, where possible, or in the laboratory. Water samples for each chemical analysis were stored in pre-cleaned, amber, glass bottles. Following collection, samples were chilled immediately for shipment to the appropriate laboratory. To minimize contamination, use of personal care items (perfumes, colognes, insect repellants), caffeinated products, and tobacco were discouraged during sample collection and processing, and water samples were not stored in proximity to any of these products (U.S. Geological Survey, 2003).

\section{Analytical Methods}

Several analytical methods were used to determine the extent of occurrence of OWCs in ground- and surface-water samples for both studies. The ground-water reconnaissance used three analytical methods (Brown and others, 1999; Cahill and others, 2004; Meyer and others, 2007) to determine the occurrence of 65 OWCs in ground water. The source-water reconnaissance used three analytical methods (Cahill and others, 2004; Zaugg and others, 2006; Meyer and others, 2007) to determine the occurrence of 100 OWCs in untreated sources of public-drinking water. Nineteen antibiotic compounds (ground-water reconnaissance) and 22 antibiotic compounds (source-water reconnaissance) were extracted and analyzed by tandem solid-phase extraction (SPE) and single quadrapole, liquid chromatography/mass spectrometry (LC/MS) with electro-spray ionization set in positive mode and selected-ion monitoring (SIM) (Meyer and others, 2007; hereafter referred to as ANT LC/MS, table 2). In both studies, 16 human prescription and non-prescription drugs and their select metabolites were extracted by SPE and analyzed by high-performance liquid chromatography (HPLC) using a polar reverse-phase octylsilane (C8) HPLC column (Cahill and others, 2004; hereafter referred to as PHARM LC/MS, table 3). For the groundwater reconnaissance study, 30 OWC-related compounds were extracted using continuous liquid-liquid extraction (CLLE) and analyzed by capillary-column gas chromatography/mass spectrometry (GC/MS) with SIM (Brown and others, 1999; hereafter referred to as CLLE SIM GC/MS, table 4). Fiftynine compounds in the source-water reconnaissance study were extracted from whole-water samples using CLLE and analyzed by capillary-column GC/MS (Zaugg and others, 2006; hereafter referred to as CLLE GC/MS). Five compounds (caffeine, codeine, cotinine, sulfamethoxazole, and trimethoprim) were analyzed by more than one method in the groundwater reconnaissance study. Also, five compounds (caffeine, cotinine, azithromycin, sulfamethoxazole, and trimethoprim) were analyzed by more than one analytical method in the source-water reconnaissance study.

Tables are available in Excel format:

- Table 2. Samples collected from surface- and groundwater sites analyzed for selected antibiotic analytes in 2000 and 2001.

- Table 3. Samples collected from surface- and groundwater sites analyzed for selected human pharmaceutical analytes in 2000 and 2001.

- Table 4. Samples collected from surface- and groundwater sites analyzed for selected organic wastewater analytes in 2000 and 2001.

All analytical methods have been continuously evaluated, developed, and revised during recent years as new laboratory and field data have become available throughout the USGS and as research objectives have evolved. These evaluations 


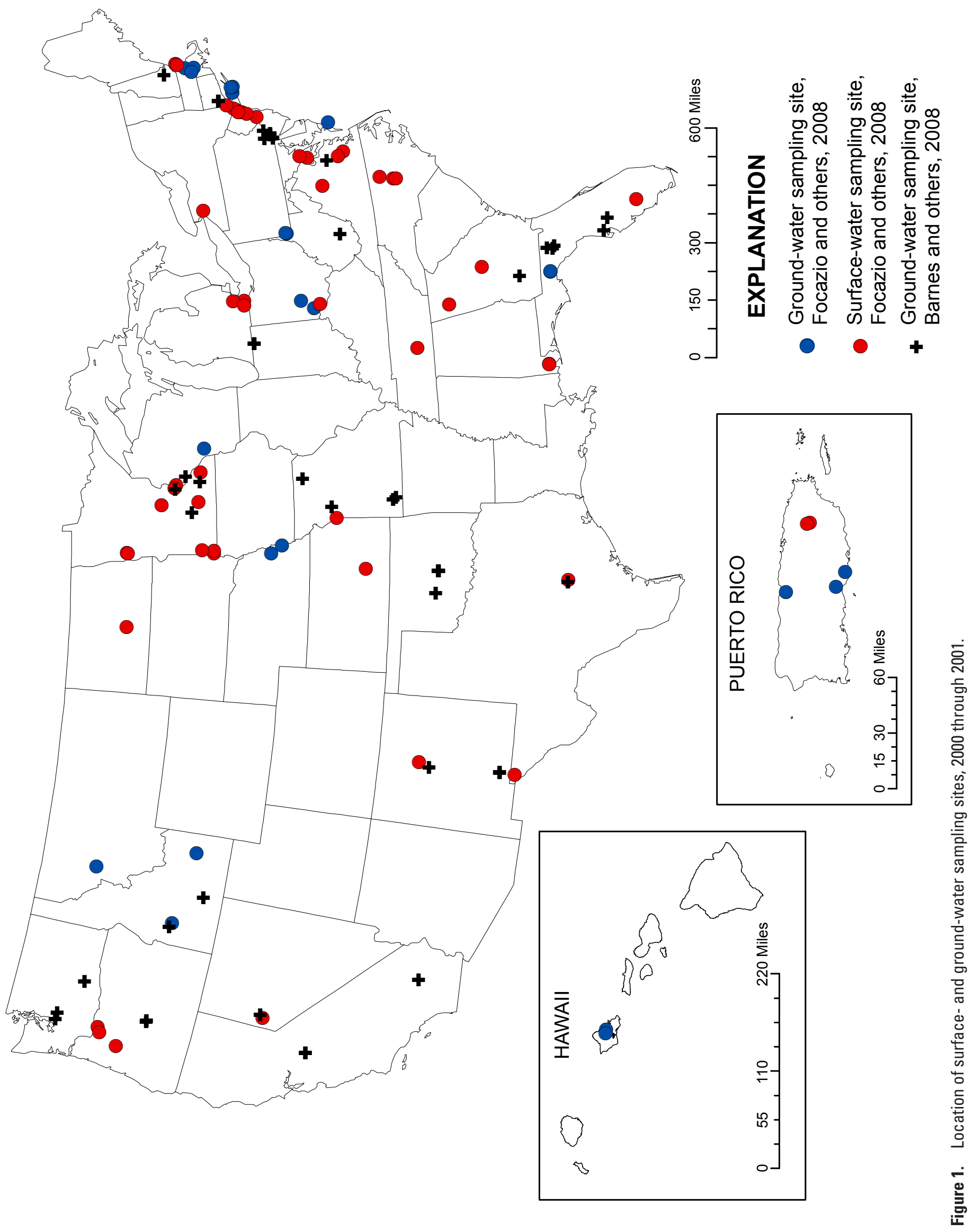


include new information, insights, and focused studies on matrix interferences, laboratory and field contamination, and interlaboratory comparisons. A limited number of method performance and reporting level changes resulted from these evaluations. To provide consistent and up-to-date analysis across methods and compounds, all environmental data are reported using the most recent evaluations and determinations regarding these methods and reporting criteria. For example, the selected-ion monitoring mode GC/MS method with CLLE previously used by the ground-water study (Barnes and others, 2008) was changed to a full-scan monitoring mode at the time of the source-water reconnaissance. This simple but important change to the method decreased detection sensitivity, but enabled detection of a broader suite of compounds, an important tradeoff for reconnaissance and occurrence research.

Results from compounds measured by more than one analytical method were compared and evaluated to determine the most reliable method on a compound-by-compound specific basis. This evaluation yielded "primacy" methods for each specific compound. For example, cotinine and caffeine are measured by the PHARM LC/MS and the CLLE GC/ MS method; however, the detection levels are lower with the PHARM LC/MS method, and therefore, it is used to report environmental data. Detailed descriptions of the methods and method performance characteristics are provided elsewhere (Brown and others, 1999; Cahill and others, 2004; Zaugg and others, 2006; Meyer and others, 2007; Barnes and others, 2008; and Focazio and others, 2008).

\section{Quality Assurance and Quality Control}

U.S. Geological Survey personnel collect and analyze field and laboratory field blank data for all methods continuously as part of ongoing research and evaluation. These data, along with other criteria including new information, insights, and focused studies on matrix interferences, laboratory and field contamination, and interlaboratory comparisons, are considered in setting or adjusting the method reporting levels (RL) for each compound and making general decisions on how to report data. All RLs and related reporting decisions are based on quality assurance/quality control (QA/QC) from each project and all other preceding USGS projects where possible.

Field blanks, consisting of laboratory-grade, organic-free water, through all the steps of sampling, processing, handling, and equipment as the regular samples, were submitted for 13 of 121 sites (table 5). For further details, see the interpretive reports for the ground-water reconnaissance study (Barnes and others, 2008) and the study of untreated drinking water sources (Focazio and others, 2008).

- Table 5. Quality-assurance samples from surface- and ground-water sites analyzed in 2000 and 2001 (Excel format).

\section{Naturally Occurring Organic Wastewater Contaminants}

The compounds analyzed in the companion studies (Focazio and others, 2008; Barnes and others, 2008), were targeted because they are believed to indicate human- and animal-waste sources to the environment, although many also occur naturally. These sources include private, municipal, and animal agricultural solid and liquid wastes and are assumed to enter the environment through various direct (point source) and indirect (non-point source) pathways. Many of these compounds can be transported to surface and ground water through natural watershed and aquifer processes; therefore, the occurrence of these naturally occurring compounds alone may not indicate a human- or animal-waste source. Conversely, some of the compounds are incorporated in various commercial products and by-products, and may be biosynthesized in large-scale commercial applications and subsequently may become concentrated in human- and animal-waste-source pathways to the environment.

Seventeen of the 65 compounds targeted by Barnes and others (2008) and 31 of the 100 compounds targeted by Focazio and others (2008) are known or suspected to have at least some natural sources (table 6). Details of the potential natural sources are beyond the scope of this report, but may come from microorganisms, plant or animal sources, and may include by-products of combustion or other natural processes (table 6). The sources listed here are not intended to be an exhaustive list of all possible sources of each compound; it is possible there are some natural sources for other compounds analyzed in the companion reports (Barnes and others, 2008; Focazio and others, 2008) that are not listed here.

- Table 6. Naturally occurring compounds (Excel format).

The compounds targeted are a range of organic compounds with various potential known or suspected ecological and/or human-health effects. The companion reports (Barnes and others, 2008; Focazio and others, 2008) include citations for selected health-related information, water-quality standard, or other relevant factors for each target compound and include the predominant use categories and discussions of potential source pathways to the environment where possible. Summarizing statistics in the companion reports aggregate all synthetic and naturally occurring compounds regardless of potential pathways to water resources. Additional analysis is required to identify naturally occurring compounds with concentrations that might indicate a human- or animal-wastesource pathway. 


\section{Occurrence of Pharmaceuticals and Organic Wastewater Contaminants}

Several studies document the occurrence of a variety of manmade and natural organic compounds such as pharmaceuticals, steroids, surfactants, flame retardants, fragrances, and other compounds often associated with wastewaters and livestock agricultural facilities in water resources (Ternes, 1998; Stumpf and others, 1999; Heberer and others, 2001; Kolpin and others, 2002; Metcalf and others, 2003, Hohenblum and others, 2004, Moldovan, 2006; Kim and others, 2007). Results from ground-water samples collected in 2000 and ground- and surface-water samples representing untreated drinking water sources collected in the summer of 2001 are given in tables 2 to 5 .

\section{Ground-Water Reconnaissance}

At least one OWC was detected in 81 percent of the ground-water sites sampled in 2000. More than one-half of the OWCs (35 out of 65) were detected at least once during this study. The overall frequency of detection was likely affected by the study design. Measured concentrations generally were low, with 124 of 137 (87 percent) detections being less than 1 microgram per liter $(\mu \mathrm{g} / \mathrm{L})$. The most frequently detected compounds are $\mathrm{N}, \mathrm{N}$-diethyltoluamide (35 percent, insect repellant), bisphenol A (30 percent, plastic- and epoxy-manufacturing ingredient), tri(2-chloroethyl) phosphate (30 percent, fire retardant), sulfamethoxazole (23 percent, veterinary and human antibiotic), and 4-octylphenol monoethoxylate (19 percent, detergent metabolite). Mixtures were prevalent with more than one compound being detected at 25 of 47 sites and 10 or more compounds detected at 3 sites. The maximum number of compounds detected at any particular site was 14 with a median of 2 . The interpretive summary of this study is available in Barnes and others (2008).

\section{Reconnaissance of Untreated Sources of Drinking Water}

Sixty-three of the 100 targeted compounds were detected in at least one water sample. In spite of the low detection levels, 60 percent of the 36 pharmaceutical analytes (including 33 prescription drugs and antibiotics) were not detected in any water sample. The five most frequently detected targeted compounds in surface water were cholesterol (59 percent, natural sterol), metolachlor (53 percent, herbicide), cotinine (51 percent, nicotine metabolite), $\beta$-sitosterol (37 percent, natural plant sterol), and 1,7-dimethylxanthine (27 percent, caffeine metabolite). The five most frequently detected compounds in ground water were tetrachloroethylene ( 24 percent, solvent), carbamazepine ( 20 percent, pharmaceutical), bisphenol A (20 percent, plastic- and epoxy-manufacturing ingredient), 1,7-dimethylxanthine (16 percent, caffeine metabolite), and tri (2-chloroethyl) phosphate (12 percent, fire retardant). The median number of compounds detected at a site was four, indicating that the targeted compounds generally occur in mixtures (commonly near detection levels) in the environment and likely originate from a variety of animal and human uses and waste sources. The interpretive summary of this study is available in Focazio and others (2008).

\section{Acknowledgments}

The authors acknowledge the many USGS scientists and field technicians providing assistance in site selection, collection, and processing of surface-water and ground-water samples and on-going collection and analysis of QA/QC data. We also thank the many public water purveyors and the American Water Works Association for providing assistance and permission to collect source-water samples at selected intake locations. Finally, the authors thank the U.S. Environmental Protection Agency, Office of Ground Water and Drinking Water, for their support of the source-water reconnaissance. This project was conducted by the USGS Toxic Substances Hydrology Program. The use of trade, firm, or brand names in this paper is for identification purposes only and does not constitute endorsement by the USGS.

\section{References Cited}

Ashton, D., Hilton, M., and Thomas, K.V., 2004, Investigating the environmental transport of human pharmaceuticals to streams in the United Kingdom: Science of the Total Environment, v. 333, p. 167-184.

Barnes, K.K., Kolpin, D.W., Furlong, E.T., Zaugg, S.D., Meyer, M.T., and Barber, L.B., 2008, A national reconnaissance of pharmaceuticals and other organic wastewater contaminants in the United States-I) Groundwater: Science of the Total Environment, v. 402, no. 2-3, p. 192-200.

Brown, G.K., Zaugg, S.D., and Barber, L.B., 1999, Wastewater analysis by gas chromatography/mass spectrometry, in Morganwalp, D.W., and Buxton H.T., eds., U.S. Geological Survey Toxic Substances Hydrology Program-Proceedings of the Technical Meeting, Charleston, South Carolina, March 8-12, 1999-Volume 2 of 3-Contamination of hydrologic systems and related ecosystems: U.S. Geological Survey Water-Resources Investigations Report 99-4018B, p. 431-435. 
Cahill, J.D., Furlong, E.T., Burkhardt, M.R., Kolpin, D.W., and Anderson, L.G., 2004, Determination of pharmaceutical compounds in surface- and ground-water samples by solidphase extraction and high-performance liquid chromatography-electrospray ionization mass spectrometry: Journal of Chromatography, v. 1041, p. 171-180.

Clara, M., Strenn, B., Gans, O., Martinez, E., Kreuzinger, N., and Kroiss, H., 2005, Removal of selected pharmaceuticals, fragrances and endocrine disrupting compounds in a membrane bioreactor and conventional wastewater treatment plants: Water Research, v. 39, p. 4,797-4,807.

Daughton, C.G., and Ternes, T.A., 1999, Pharmaceuticals and personal care products in the environment-Agents of subtle change?: Environmental Health Perspectives, v. 107 (Supplement 6), p. 907-938.

Focazio, M.J., Kolpin, D.W., Barnes, K.K., Furlong, E.T., Meyer, M.T., Zaugg, S.D., Barber, L.B., and Thurman, E.M., 2008, A national reconnaissance for pharmaceuticals and other organic wastewater contaminants in the United States-II) Untreated drinking water sources: Science of the Total Environment, v. 402, no. 2-3, p. 201-216.

Glassmeyer, S.T., Furlong, E.T., Kolpin, D.W., Cahill, J.D., Zaugg, S.D., Werner, S.L., Meyer, M.T., and Kryak, D.D., 2005, Transport of chemical and microbial compounds from known wastewater discharges-Potential for use as indicators of human fecal contamination: Environmental Science and Technology, v. 39, p. 5,157-5,169.

Halling-Sorensen, B., Nielson, S.N., Lanzky, P.F., Ingerslev, F., Holten Lutzhoft, H.C., and Jorgensen, S.E., 2002, Occurrence, fate and effects of pharmaceutical substances in the environment-A review: Chemosphere, v. 36, no. 2, p. 357-393.

Heberer, T., Furhmann, B., Schmidt-Baumler, K., Tsipi, D., Koutsouba, V., and Hiskia, A., 2001, Occurrence of pharmaceutical residues in sewage, river, ground, and drinking water in Greece and Berlin (Germany), in Daughton, C.G., and Jones-Lepp, T.L., eds., American Chemical Society Symposium Series 791: Pharmaceuticals and personal care products in the environment, Scientific and regulatory issues, $396 \mathrm{p}$.

Heberer, T., 2002a, Tracking persistent pharmaceutical residues from municipal sewage to drinking water: Journal of Hydrology, v. 266, p. 175-189.

Heberer, T., 2002b, Occurrence, fate, and removal of pharmaceutical residues in the aquatic environment-A review of the recent research data: Toxicology Letters, v. 131, p. 5-17.

Hignite, C., and Azarnoff, D.L., 1977, Drugs and drug metabolites as environmental contaminants-Chlorophenoxyisobutyrate and salicylic acid in sewage water effluent: Life Sciences, v. 20, p. 337-341.
Hohenblum, P., Gans, O., Moche, W., Scharf, S., and Lorbeer, G., 2004, Monitoring of selected estrogenic hormones and industrial chemicals in ground waters and surface waters in Austria: Science of the Total Environment, v. 333, p. 185-193.

Kim, S.D., Cho, J., Kim, I.S., Vanderford, B.J., and Snyder, S.A., 2007, Occurrence and removal of pharmaceutical and endocrine disruptors in South Korean surface, drinking, and waste waters: Water Research, v. 41, p. 1,013-1,021.

Kolpin, D.W., Furlong, E.T., Meyer, M.T., Thurman, E.M., Zaugg, S.D., Barber, L.B., and Buxton, H.T., 2002, Pharmaceuticals, hormones, and other organic wastewater contaminants in U.S. Streams, 1999-2000-A National Reconnaissance: Environmental Science and Technology, v. 36, p. 1,202-1,211.

Lindqvist, N., Tuhkanen, T., and Kronberg, L., 2005, Occurrence of acidic pharmaceuticals in raw and treated sewages and in receiving waters: Water Research, v. 39, p. 2,219-2,228.

Metcalf, C.D., Miao, X.-S., Koenig, B.G., and Struger, J., 2003, Distribution of acidic and neutral drugs in surface waters near sewage treatment plants in the lower Great Lakes, Canada: Environmental Toxicology and Chemistry, v. 22, p. 2,281-2,889.

Meyer, M.T., Lee, E.A., Ferrell, G.F., Bumgarner, J.E., and Varns, J., 2007, Evaluation of offline tandem and online solid-phase extraction with liquid chromatography/mass spectrometry for the analysis of antibiotics in ambient water and comparison to an independent method: U.S. Geological Survey Scientific Investigations Report 2007-5021, 28 p.

Miao, X.-S., Yang, J.-J., and Metcalfe, C.D., 2005, Carbamazepine and its metabolites in wastewater and in biosolids in a municipal wastewater treatment plant: Environmental Science and Technology, v. 39, p. 7,469-7,475.

Moldovan, Z., 2006, Occurrences of pharmaceutical and personal care products as micropollutants in rivers from Romania: Chemosphere, v. 64, p. 1,808-1,817.

Paxeus, N., 2004, Removal of selected non-steroidal antiinflammatory drugs (NSAIDs), gemfibrozil, carbamazepine, beta-blockers, trimethoprim and triclosan in conventional wastewater treatment plants in five EU countries and their discharge to the aquatic environment: Water Science and Technology, v. 50, p. 253-260.

Reiner, J.L., Berset, J.D., Kannan, K., 2007, Mass flow of polycyclic musks in two wastewater treatment plants: Archives of Environmental Contamination and Toxicology, v. 52, p. $451-457$. 
Stumpf, M., Ternes, T.A., Wilken, R.D., Rodrigues, S.V., and Baumann, W., 1999, Polar drug residues in sewage and natural waters in the state of Rio de Janeiro, Brazil: Science of the Total Environment, v. 225, p. 135-141.

Ternes, T.A., 1998, Occurrence of drugs in German sewage treatment plants and rivers: Water Resources, v. 32, p. 3,245-3,260.

U.S. Geological Survey, 2003, National field manual for the collection of water-quality data: U.S. Geological Survey Techniques of Water-Resources Investigations, book 9, chap. A5, accessed February 2008 at http://pubs.water.usgs. gov/twri9A
U.S. Geological Survey, 2006, National field manual for the collection of water-quality data: U.S. Geological Survey Techniques of Water-Resources Investigations, book 9, chap. A4, accessed February 2008 at http://pubs.water.usgs. gov/twri9A

Wiegel, S., Aulinger, A., Brockmeyer, R., Harms, H., Loffler, J., Reincke, H., Schmidt, R., Stachel, B., von Tumpling, W., and Wanke, A., 2004, Pharmaceuticals in the river Elbe and its tributaries: Chemosphere, v. 57, p. 107-126.

Zaugg, S.D., Smith, S.G., and Schroeder, M.P., 2006, Determination of wastewater compounds in whole water by continuous liquid-liquid extraction and capillary-column gas chromatography/mass spectrometry: U.S. Geological Survey Techniques and Methods, book 5, chap. B4.
Publishing support provided by:

Rolla Publishing Service Center

For more information concerning this publication, contact: Director, USGS lowa Water Science Center

P.O. Box 1230

lowa City, IA 52244

(319) 337-4191

Or visit the lowa Water Science Center Web site at: 
